Supporting Information

\title{
Ethanol as a Liquid Organic Hydrogen Carrier for Seasonal Microgrid Application: Catalysis, Theory, and Engineering Feasibility
}

\author{
Ba L. Tran, ${ }^{\star a}$ Samantha I. Johnson, ${ }^{a}$ Kriston P. Brooks, ${ }^{a}$ S. Tom Autreya \\ aPacific Northwest National Laboratory, Richland, WA 99352 \\ *Email: ba.tran@pnnl.gov
}

\section{Table of Contents}

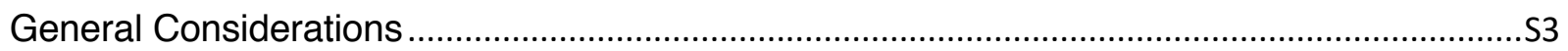

General treatment of EtOH prior to dehydrogenation reactions .............................................S3

Procedure for continuous dehydrogenation reactions of $\mathrm{EtOH}$................................................S3

Procedure for dehydrogenation and hydrogenation reactions from $\mathrm{EtOH} \ldots \ldots \ldots \ldots \ldots \ldots \ldots \ldots \ldots \ldots \ldots . . .54$

Figure S1A. Summary of dehydrogenations of EtOH catalyzed by Ru-MACHO (250 ppm) at $90^{\circ} \mathrm{C}$ over three runs with fresh addition of $\mathrm{EtOH}$ and $1.30 \mathrm{~mol} \% \mathrm{NaOEt}$ to $\mathrm{EtOH}$.................S5

Figure S1B. Summary of the results for the cycles of dehydrogenation and hydrogenation catalyzed by a single catalyst system..................................................................................... 5

Figure S2. ${ }^{1} \mathrm{H}$ NMR data for the dehydrogenation and hydrogenation cycles of $\mathrm{EtOH}$ and EtOAc using the same EtOH and the same Ru catalyst mixture. ............................................S6

Demonstrating the hydrogenation reaction at lower pressure of $\mathrm{H}_{2} \ldots \ldots \ldots \ldots \ldots \ldots \ldots \ldots \ldots \ldots \ldots \ldots \ldots \ldots . . . . .56$

Figure S3. ${ }^{1} \mathrm{H}$ NMR data for the Ru-catalyzed hydrogenation of EtOAc to EtOH at 14 bar of $\mathrm{H}_{2}$

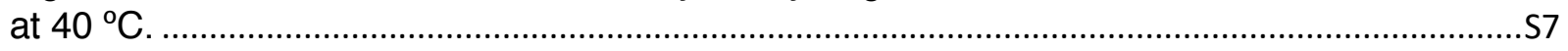

General procedure for temperature-dependent studies for the dehydrogenation of EtOH.......S7

Figure S4A. A representative array of the ${ }^{1} \mathrm{H}$ NMR data for the Ru-catalyzed dehydrogenation of $\mathrm{EtOH}$ at $70{ }^{\circ} \mathrm{C}$ over a period of $6 \mathrm{~h}$. Not shown are resonances of toluene $\mathrm{Ar}-\mathrm{H}$ and $\mathrm{CDCl}_{3}$

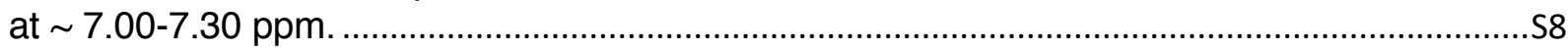

Figure S4B. Eyring plot: $\Delta H^{\ddagger}=54.1 \mathrm{~kJ} / \mathrm{mol}, \Delta S^{\ddagger}=-149.6 \mathrm{~J} / \mathrm{mol} \cdot \mathrm{K}, \Delta G^{\ddagger}=98.7 \mathrm{~kJ} / \mathrm{mol}(298 \mathrm{~K})$.

Figure S5. A comparative study on the effect of pretreated EtOH and untreated, wet, out-ofthe-bottle $\mathrm{EtOH}$ in the Ru-catalyzed dehydrogenation of $\mathrm{EtOH}$ at $70^{\circ} \mathrm{C}$. .S9 Methods and Molecular Geometries. .59 
Figure S6. EtOH dehydrogenation steps. All free energies in $\mathrm{kJ} / \mathrm{mol}$. Green energies are in $\mathrm{EtOH}$ solvent, purple energies are in EtOAc solvent, and blue energies are in the gas phase.

Figure S7. Hemiacetal dehydrogenation steps. All free energies in kJ/mol. Green energies are in $\mathrm{EtOH}$ solvent and blue energies are in the gas phase.

Figure S8. Hydrogen evolution steps from catalyst ground state. All free energies in kJ/mol.

Green energies are in EtOH solvent and blue energies are in the gas phase.

Figure S9. Deactivation pathway through water binding to form an acetate complex.

Supplementary Material for Table 1

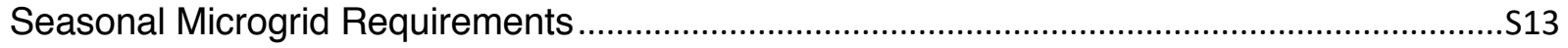

Impact of Ethanol and Ethyl Acetate Vapor Pressure.............................................................S13

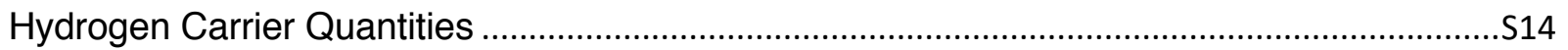

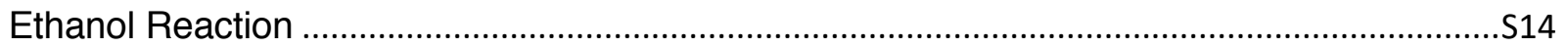

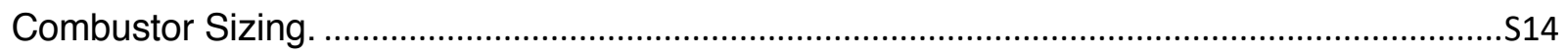

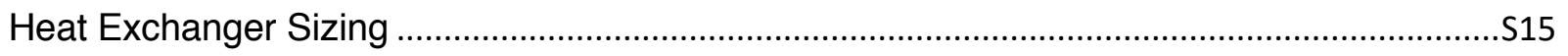

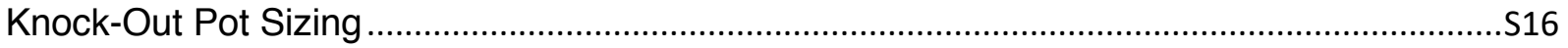

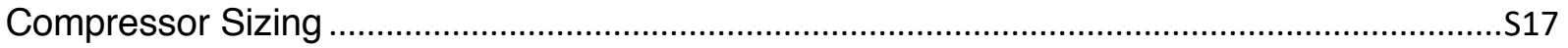

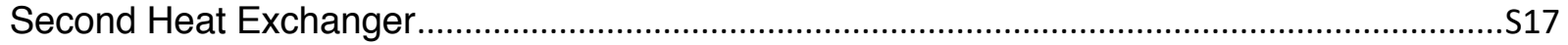

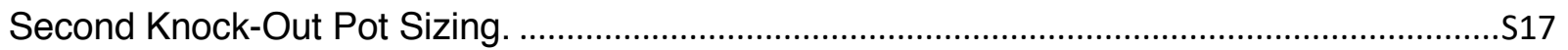

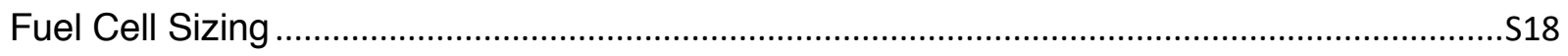

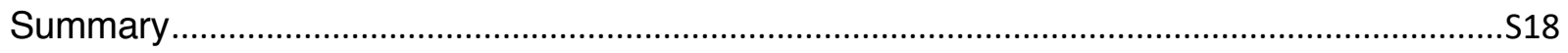

Table SA.1: Material, Tank and Reaction Properties for a ...................................................S18

seasonal microgrid hydrogen storage system based on ethanol/ethyl acetate.......................S18

Table SA.2: Combustor, Fuel Cell, Compressor, Knock-Out Pot, and Heat Exchanger

Properties for a seasonal microgrid hydrogen storage system based on ethanol/ethyl acetate

References ..S20 


\section{General Considerations}

All reactions were conducted under a nitrogen atmosphere unless otherwise noted. All reagents were purchased and used as received unless otherwise noted. Anhydrous solvents were purified by passage through neutral alumina using an Innovative Technology, Inc., PureSolv solvent purification system. NMR spectra were acquired on a $500 \mathrm{MHz}$ NMR spectrometer. Chemical shifts are reported in ppm relative to a residual solvent peak $\mathrm{CDCl}_{3}=7.26 \mathrm{ppm}$ for ${ }^{1} \mathrm{H}$ NMR spectroscopy and $77.23 \mathrm{ppm}$ for ${ }^{13} \mathrm{C}$ NMR spectroscopy. Ru-MACHO (MLD Number MFCD22377801) was purchased from STREM chemicals and used as received. 200 Proof anhydrous (99.5\%) was purchased from Fischer Scientific.

\section{General treatment of EtOH prior to dehydrogenation reactions}

To an oven-dried $500 \mathrm{~mL}$ Schlenk round-bottom flask was charged with $300 \mathrm{~mL}$ of ethanol, obtained from the PureSolv solvent purification system, and a large egg-shaped stirring bar. The mixture was vigorously stirred at $25^{\circ} \mathrm{C}$. The ethanol was degassed by immersing a long needle attached to a Tygon tubing from the Schlenk manifold. After $1 \mathrm{~h}$ of vigorous stirring and purging with $\mathrm{N}_{2}$, under a positive flow of $\mathrm{N}_{2}$ was charged with activated $4 \AA$ molecular sieves. The needle was removed and the Schlenk tube was fitted a 24/40 glass stopper. The ethanol was stored for $24 \mathrm{~h}$ before use.

\section{Procedure for continuous dehydrogenation reactions of EtOH}

Inside a nitrogen-filled glovebox, a $3 \mathrm{~mL}$ scintillation vial was charged with Ru-MACHO (13.0 mg, $250 \mathrm{ppm}, 0.0214 \mathrm{mmol}$ ) and $1.30 \mathrm{~mol} \% \mathrm{NaOEt}(76.0 \mathrm{mg}, 1.12 \mathrm{mmol})$ with respect to EtOH. This mixture was removed from the glovebox and was added to an oven-dried $50 \mathrm{~mL}$ Schlenk tube containing a stirring bar. Under a positive flow of $\mathrm{N}_{2}$, ethanol $(5.00 \mathrm{~mL}, 85.6 \mathrm{mmol})$ was added via syringe from a round-bottom flask containing EtOH in $4 \AA$ molecular sieves under a positive flow of $\mathrm{N}_{2}$. The Schlenk tube was fitted with a reflux condenser and lowered into a pre-heated oil bath. The reaction was allowed to proceed at $90{ }^{\circ} \mathrm{C}$ for $20 \mathrm{~h}$ under a constant stream of $\mathrm{N}_{2}$. The conversion of the reaction was determined by taking in aliquot of the reaction mixture in $\mathrm{CDCl}_{3}$ and analyzed by ${ }^{1} \mathrm{H}$ NMR spectroscopy.

For continuous dehydrogenation, Schlenk tube was removed from the heated oil bath and fresh $\mathrm{EtOH}(5 \mathrm{~mL}, 85.6 \mathrm{mmol})$ and NaOEt $(76.0 \mathrm{mg}, 1.12 \mathrm{mmol})$ were added under a positive flow of $\mathrm{N}_{2}$. The reaction mixture was again lowered into the heated oil bath for another $20 \mathrm{~h}$ at $90{ }^{\circ} \mathrm{C}$. This can repeat for another cycle to give consistent results for the EtOH dehydrogenation for up to 3 cycles. The rates for run 3 are sluggish. It is not clear if the sluggish rates are due to dilution or flooding excess of NaOEt base. 


\section{Procedure for dehydrogenation and hydrogenation reactions from EtOH}

\section{Cycle 1 for dehydrogenation}

Inside a nitrogen-filled glovebox, a $3 \mathrm{~mL}$ scintillation vial was charged with Ru-MACHO (13.0 mg, $250 \mathrm{ppm})$ and $1.30 \mathrm{~mol} \% \mathrm{NaOEt}(76.0 \mathrm{mg}, 1.12 \mathrm{mmol})$ with respect to EtOH. This mixture was removed from the glovebox and was added to an oven-dried $50 \mathrm{~mL}$ Schlenk tube containing a stirring bar under a positive flow of $\mathrm{N}_{2}$. To this Schlenk tube, ethanol $(5.00 \mathrm{~mL}, 85.6 \mathrm{mmol})$ was added via syringe from a round-bottom flask containing $\mathrm{EtOH}$ and $4 \AA$ molecular sieves under a positive flow of $\mathrm{N}_{2}$. The Schlenk tube was fitted with a reflux condenser and lowered into a preheated oil bath. The reaction was allowed to proceed at $90{ }^{\circ} \mathrm{C}$ for $20 \mathrm{~h}$ under a constant stream of $\mathrm{N}_{2}$. The conversion of the reaction was determined by taking in aliquot of the reaction mixture in $\mathrm{CDCl}_{3}$ and analyzed by ${ }^{1} \mathrm{H}$ NMR spectroscopy.

\section{Cycle for hydrogenation}

The crude mixture from the dehydrogenation reaction was taken inside a nitrogen-filled glovebox and charged with $1.3 \mathrm{~mol} \% \mathrm{NaOEt}(76.0 \mathrm{mg}, 1.12 \mathrm{mmol})$. This mixture was transferred to a 25 $\mathrm{mL}$ Parr reactor, removed from the glovebox, charged with 50 bar of $\mathrm{H}_{2}$, and attached to a Parr parallel reactor setup for proper stirring and temperature regulation of $40{ }^{\circ} \mathrm{C}$. After $24 \mathrm{~h}$, the reaction mixture was analyzed by ${ }^{1} \mathrm{H}$ NMR spectroscopy to show near quantitative conversion of $97 \%$.

\section{Cycle 2 for dehydrogenation}

The Parr reactor from the hydrogenation reaction was taken inside a nitrogen-filled glovebox. The reaction mixture was transferred to a $50 \mathrm{~mL}$ Schlenk tube, removed from the glovebox, attached to a Schlenk manifold, and fitted with a reflux condenser, and lowered into a preheated oil bath at $90{ }^{\circ} \mathrm{C}$ for $20 \mathrm{~h}$ under a stream of $\mathrm{N}_{2}$. The distribution of product was analyzed by ${ }^{1} \mathrm{H}$ NMR spectroscopy. 


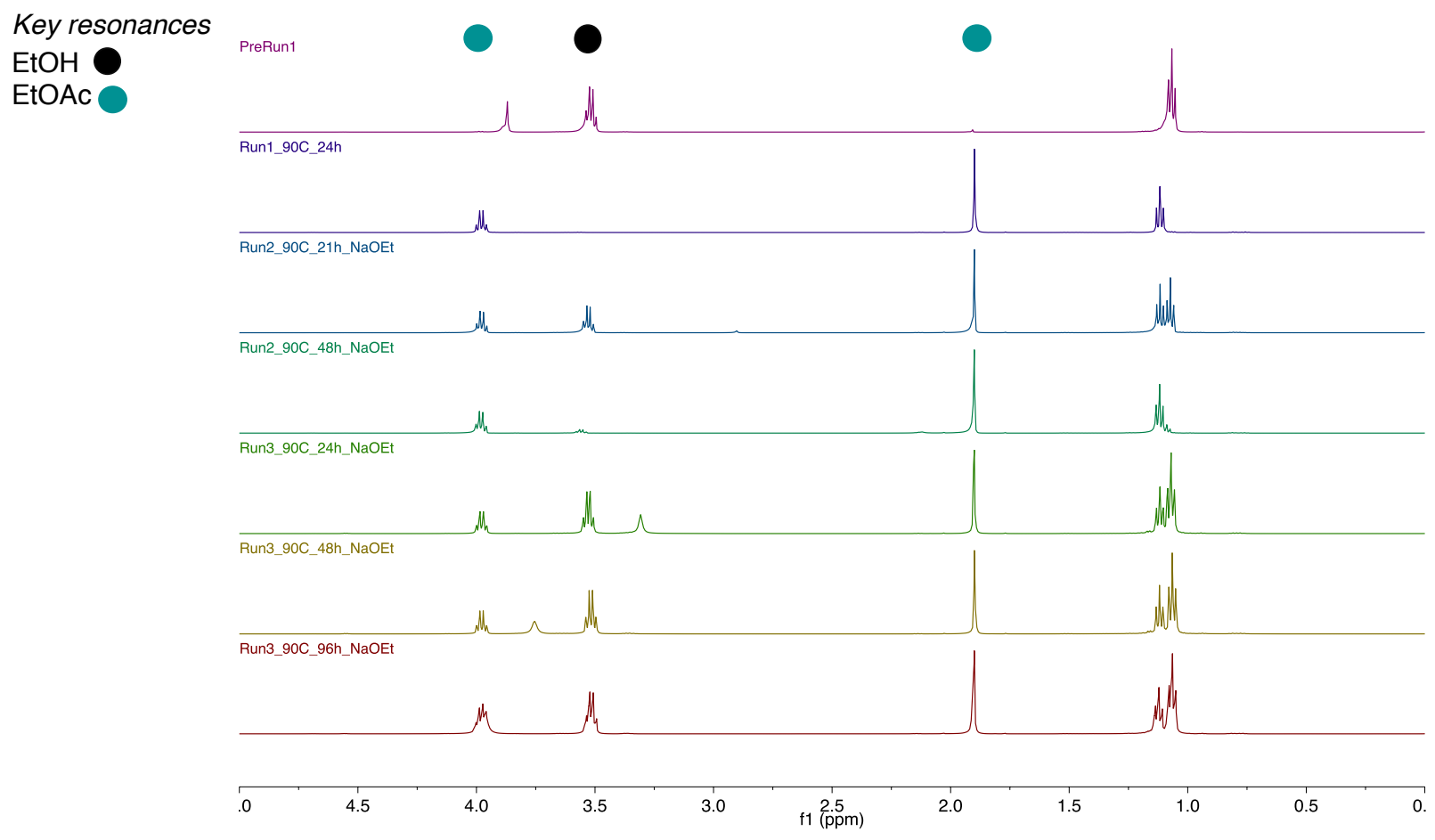

Figure S1A. Summary of dehydrogenations of EtOH catalyzed by Ru-MACHO (250 ppm) at 90 ${ }^{\circ} \mathrm{C}$ over three runs with fresh addition of $\mathrm{EtOH}$ and $1.30 \mathrm{~mol} \% \mathrm{NaOEt}$ to EtOH. Qualitatively, the catalyst was reactivated and exhibited dehydrogenation activity, however, the rates clearly become diminished after the initial run. By run 3, the rate of dehydrogenation is extremely sluggish, and the reaction progress was stopped after $96 \mathrm{~h}$.

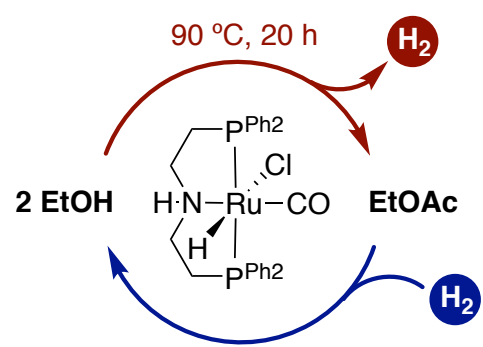

$\mathrm{H}_{2}$ (50 bar), $40{ }^{\circ} \mathrm{C}, 24 \mathrm{~h}$

Ru-MACHO 250 ppm

NaOEt $(1.30 \mathrm{~mol} \% \mathrm{w} /$ respect to $5 \mathrm{~mL}$ of $\mathrm{EtOH})$

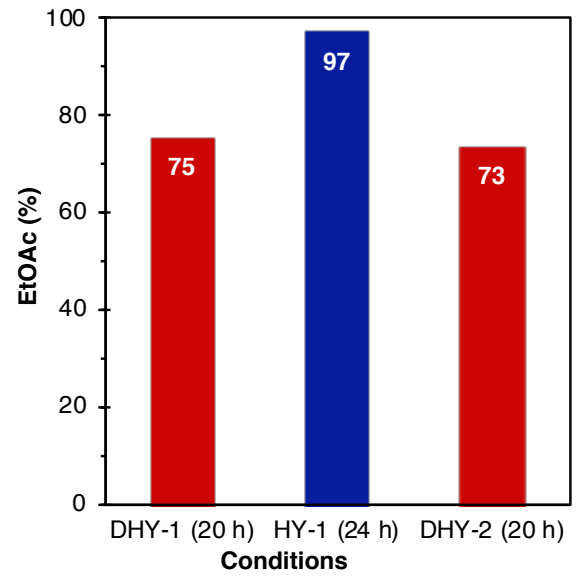

$\mathrm{DHY}=$ dehydrogenation; $\mathrm{HY}=$ hydrogenation

a) $\mathrm{HY}-1$ : added fresh $1.30 \mathrm{~mol} \% \mathrm{NaOEt}$

b) Analysis of products by ${ }^{1} \mathrm{H},{ }^{13} \mathrm{C}$ NMR spectroscopy.

Figure S1B. Summary of the results for the cycles of dehydrogenation and hydrogenation catalyzed by a single catalyst system. 


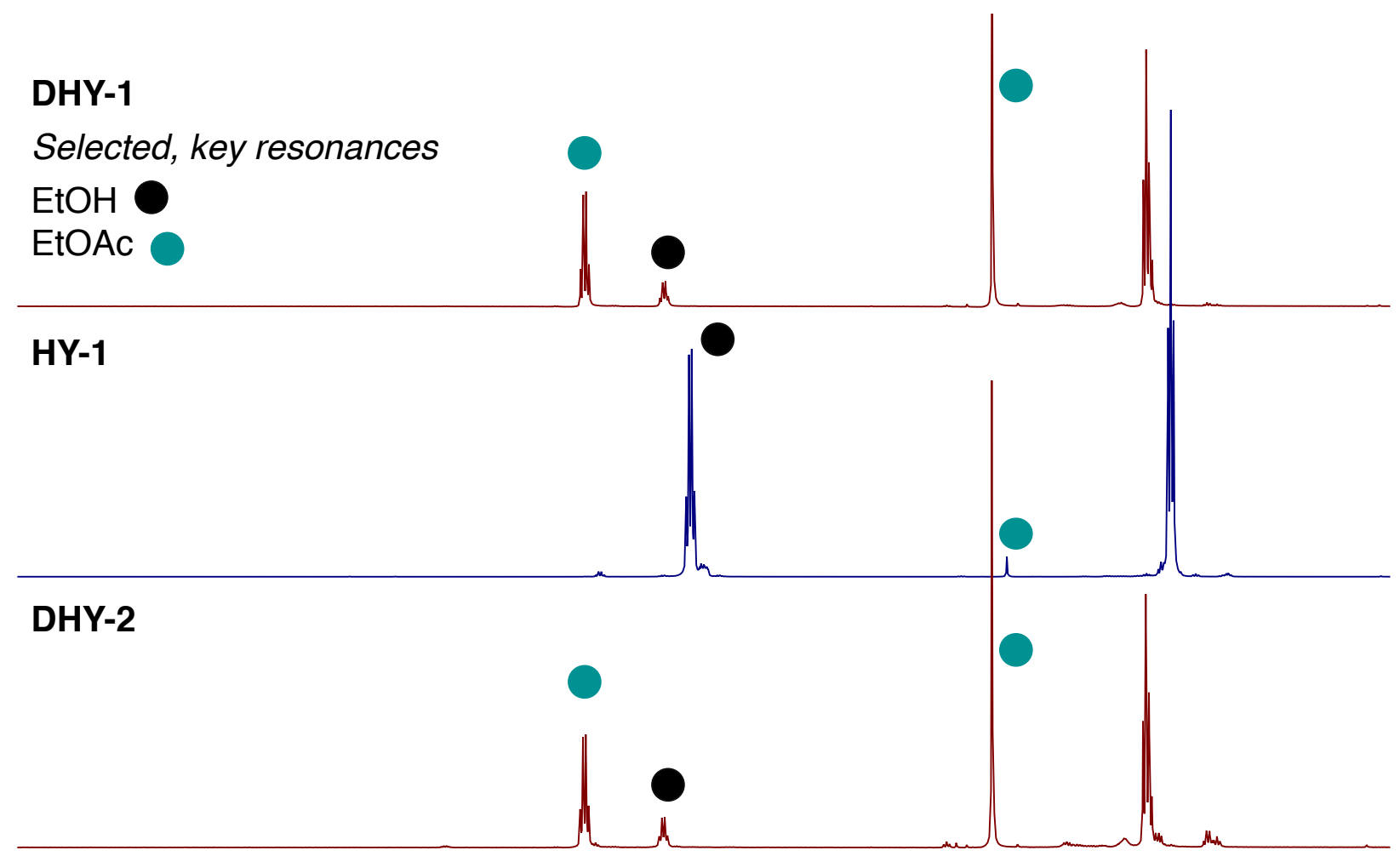

\begin{tabular}{llllllllllllll}
\hline 0 & 6.5 & 6.0 & 5.5 & 5.0 & 4.5 & 4.0 & $\mathrm{f} 1 \mathrm{3}(\mathrm{ppm})$ & 3.0 & 2.5 & 2.0 & 1.5 & 1.0 & 0.5
\end{tabular}

Figure S2. ${ }^{1 H}$ NMR data for the dehydrogenation and hydrogenation cycles of EtOH and EtOAc using the same EtOH and the same Ru catalyst mixture.

\section{Demonstrating the hydrogenation reaction at lower pressure of $\mathrm{H}_{2}$}

Inside a nitrogen-filled glovebox, to a $25 \mathrm{~mL}$ Parr reactor was added Ru-MACHO (13.0 mg, 250 ppm), $1.30 \mathrm{~mol} \% \mathrm{NaOEt}(76.0 \mathrm{mg}, 1.12 \mathrm{mmol})$ with respect, and EtOAc $(8.40 \mathrm{~mL}, 85.6 \mathrm{mmol})$ was added via syringe. The Parr reactor was tightly sealed, removed from the glovebox, charged with 14 bar of $\mathrm{H}_{2}$ and the Parr was removed from the $\mathrm{H}_{2}$ line and attached to a Parr parallel reactor setup for proper stirring and temperature regulation of $40^{\circ} \mathrm{C}$. After $12 \mathrm{~h}$, the reaction mixture was analyzed by ${ }^{1} \mathrm{H}$ NMR spectroscopy to show $50 \%$ conversion of EtOAc to EtOH. The reaction did not reach complete conversion because the Parr reactor was under static $\mathrm{H}_{2}$ pressure rather than dynamic $\mathrm{H}_{2}$ pressure, which would have supplied sufficient $\mathrm{H}_{2}$ for complete conversion. Nevertheless, the result of this hydrogenation reaction clearly demonstrate that it is feasible to achieve hydrogenation at a lowered pressure of 14 bar of $\mathrm{H}_{2}$, in which the $\mathrm{H}_{2}$ pressure can be supplied by water electrolysis technology. 


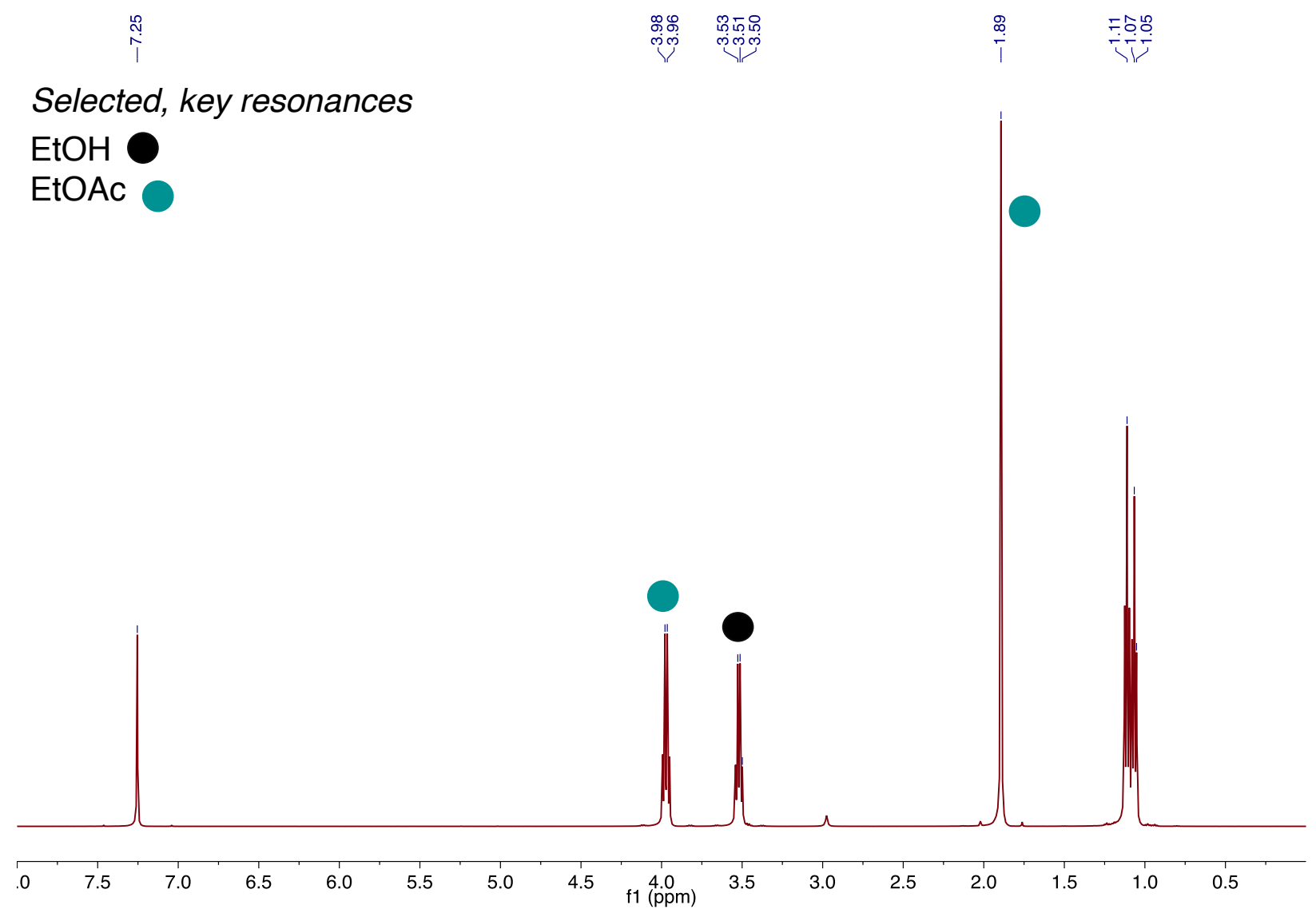

Figure S3. ${ }^{1} \mathrm{H}$ NMR data for the Ru-catalyzed hydrogenation of EtOAc to EtOH at 14 bar of $\mathrm{H}_{2}$ at $40^{\circ} \mathrm{C}$.

\section{General procedure for temperature-dependent studies for the dehydrogenation of EtOH}

Inside a nitrogen-filled glovebox, a $3 \mathrm{~mL}$ scintillation vial was charged with Ru-MACHO (13.0 mg, $250 \mathrm{ppm})$ and $1.30 \mathrm{~mol} \% \mathrm{NaOEt}(76.0 \mathrm{mg}, 1.12 \mathrm{mmol})$ with respect to EtOH). This mixture was removed from the glovebox and was added to an oven-dried $50 \mathrm{~mL}$ Schlenk tube containing a stirring bar under a positive flow of $\mathrm{N}_{2}$. Under a positive flow of $\mathrm{N}_{2}$, ethanol $(5.00 \mathrm{~mL}, 85.6 \mathrm{mmol})$ was added via syringe from a round-bottom flask containing EtOH in $4 \AA$ molecular sieves under a positive flow of $\mathrm{N}_{2}$. Lastly, an internal standard of anhydrous toluene (500 $\mu \mathrm{L}$ ) was added to the reaction mixture. The Schlenk tube was fitted with a reflux condenser equipped with a Teflon wire thermocouple for proper monitoring of the temperature of the reaction mixture. The Schlenk tube was lowered into a pre-heated oil bath at $70^{\circ} \mathrm{C}$. The conversion of the reaction was determined by analyzing an aliquot $(200 \mu \mathrm{L})$ in $500 \mu \mathrm{L}$ of $\mathrm{CDCl}_{3}$ by ${ }^{1} \mathrm{H}$ NMR spectroscopy at 1-hour interval for a total of 6 hours. The same procedure was repeated for the dehydrogenation reactions at 60 ${ }^{\circ} \mathrm{C}$ and $50^{\circ} \mathrm{C}$. 


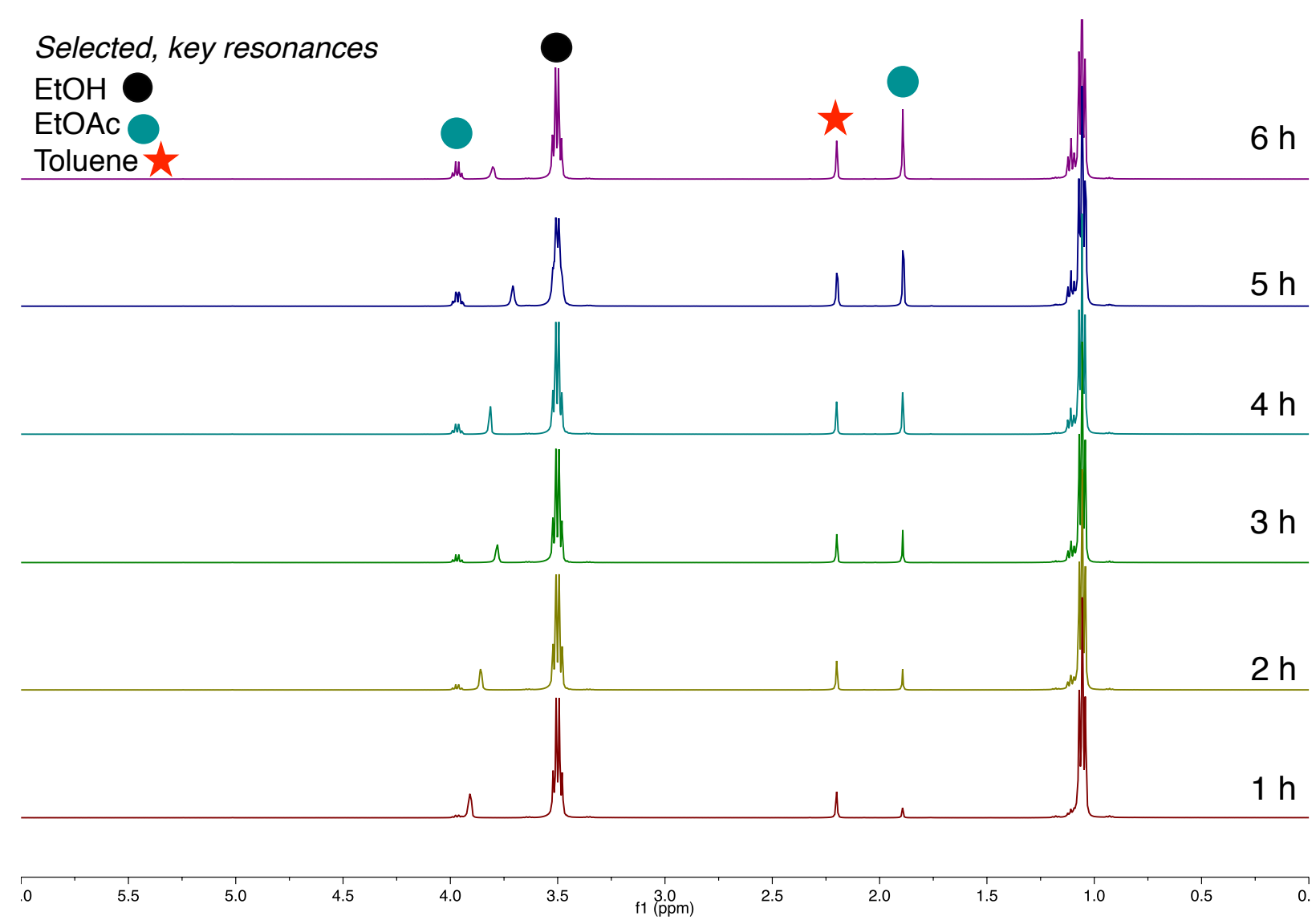

Figure S4A. A representative array of the ${ }^{1} \mathrm{H}$ NMR data for the Ru-catalyzed dehydrogenation of EtOH at $70{ }^{\circ} \mathrm{C}$ over a period of $6 \mathrm{~h}$. Not shown are resonances of toluene $\mathrm{Ar}-\mathrm{H}$ and $\mathrm{CDCl}_{3}$ at $\sim 7.00-7.30 \mathrm{ppm}$.

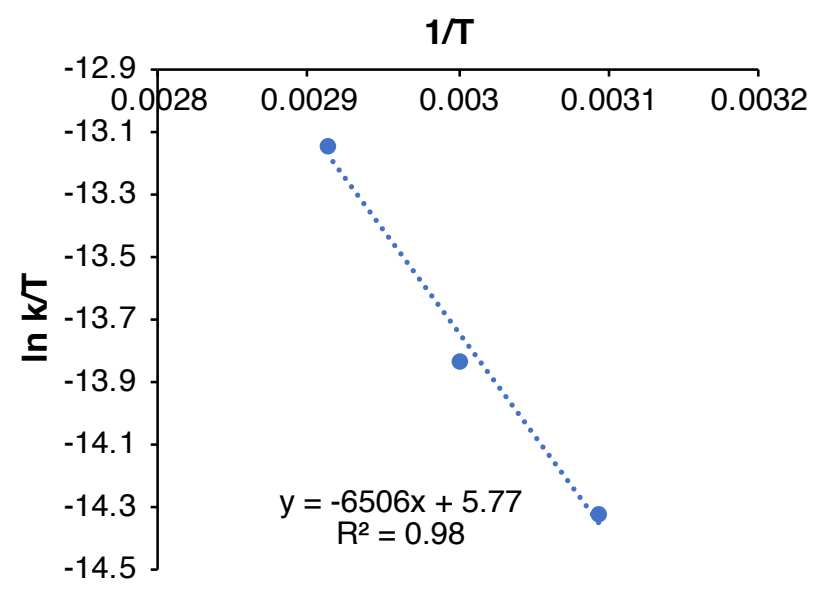

Figure S4B. Eyring plot: $\Delta H^{\ddagger}=54.1 \mathrm{~kJ} / \mathrm{mol}, \Delta S^{\ddagger}=-149.6 \mathrm{~J} / \mathrm{mol} \cdot \mathrm{K}, \Delta G^{\ddagger}=98.7 \mathrm{~kJ} / \mathrm{mol}(298 \mathrm{~K})$. 


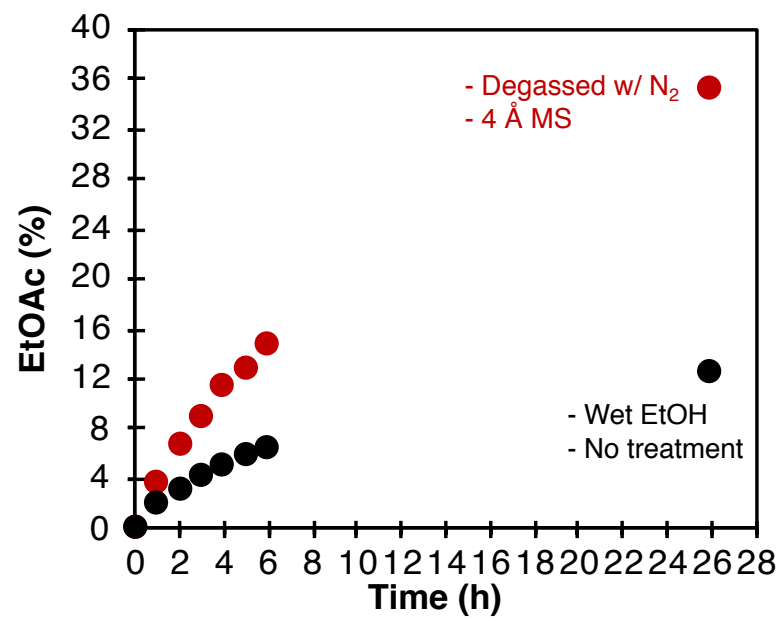

Figure S5. A comparative study on the effect of pretreated EtOH and untreated, wet, out-of-thebottle $\mathrm{EtOH}$ in the Ru-catalyzed dehydrogenation of EtOH at $70^{\circ} \mathrm{C}$. The Ru-MACHO system shows some tolerance to wet and untreated $\mathrm{EtOH}$. However, the rates of $\mathrm{H}_{2}$ release are slower than for that of the treated $\mathrm{EtOH}$. One would also assume that the rate of deactivation of the Ru$\mathrm{MACHO}$ should occur more rapidly with wet $\mathrm{EtOH}$.

\section{Methods and Molecular Geometries}

Density functional theory calculations helped to compare the energetics for on-cycles and deactivation pathways, as well as investigate the effects of catalyst modification. Geometry optimizations, frequency and solvation calculations were carried out using the B3LYP functional 1,2 utilizing the $6-31 \mathrm{G}^{\star *}$ basis set on $\mathrm{C}, \mathrm{O}, \mathrm{N}, \mathrm{P}$, and $\mathrm{H}$ atoms ${ }^{3,4}$, and the Karlsruhe def2 double- $\zeta$ basis set ${ }^{5}$ and corresponding effective core potential (ECP) on $\mathrm{Ru}^{6}$. A large basis set (def2-TZVP) calculation ${ }^{5}$ with the same ECP is used to obtain the electronic energy. The previously described frequency calculation is used to obtain the zero-point energy correction and entropic and enthalpic contributions. These frequency calculations are used to validate stationary points/intermediates on the potential energy surface, which have no imaginary frequencies, and transition states, which have a single imaginary frequency. All calculations use Grimme's D3 dispersion correction with the Becke-Johnson damping scheme. ${ }^{7,8}$ Finally, single point point solvation energies are obtained using the $\mathrm{SMD}^{9}$ solvation model. Energies in both pure ethanol reactant and ethyl acetate product are reported, as are gas phase energies. For calculations reported in pure $\mathrm{EtOH}$, the energy of $\mathrm{EtOH}$ present in the reaction is reported at $17.1 \mathrm{M}$ concentration. All other energies are reported at $298.15 \mathrm{~K}$ and $1 \mathrm{M}$ concentration. Calculations were completed using Orca 4.1.10

Cartesian coordinates of all intermediates discussed here and in the main text can be found in the accompanying .xyz file. This can be opened with any chemistry GUI or viewer, including Mercury ((https://www.ccdc.cam.ac.uk/mercury/), which can be found online free of charge. 


\section{On-Cycle Pathway}

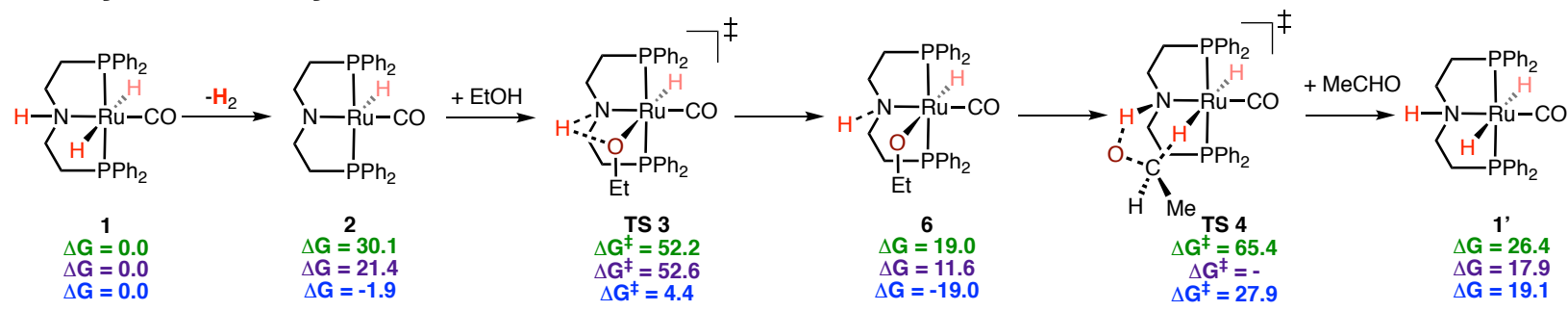

Figure S6. EtOH dehydrogenation steps. All free energies in $\mathrm{kJ} / \mathrm{mol}$. Green energies are in $\mathrm{EtOH}$ solvent, purple energies are in EtOAc solvent, and blue energies are in the gas phase.

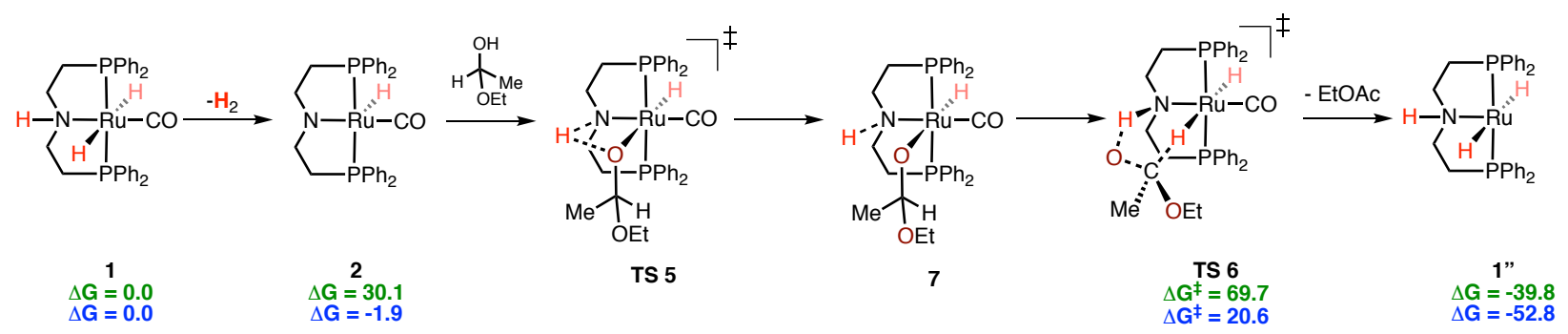

Figure S7. Hemiacetal dehydrogenation steps. All free energies in kJ/mol. Green energies are in $\mathrm{EtOH}$ solvent and blue energies are in the gas phase.

On-cycle pathway is shown here, with the common intermediate 1. These steps have previously been elucidated both for acceptorless dehydrogenative coupling (ADC) of $\mathrm{EtOH}^{11}$ and crosscoupling of alcohols and amines ${ }^{12}$. However, in order to look at the relative energetics of on-cycle and deactivation pathways, they should be calculated with consistent methods. One addition to the body of work on RuMACHO for ADC is the comparison of energetics in various solvents. In a closed system, such as a microgrid, the amount of EtOH will be depleted as it is converted to EtOAc. Current literature typically only investigates a single solvent, but as the closed system nears full conversion, the predominant solvent will be EtOAc. As we see here, the energetics shown in Fig. S6-S7 are largely similar for both solvents. EtOH is more polar than EtOAc, but since there are no changes in species charge, the ability to screen charge becomes less important. There is a much more significant change as one moves to the gas phase. 


\section{$\mathrm{H}_{2}$ Evolution}
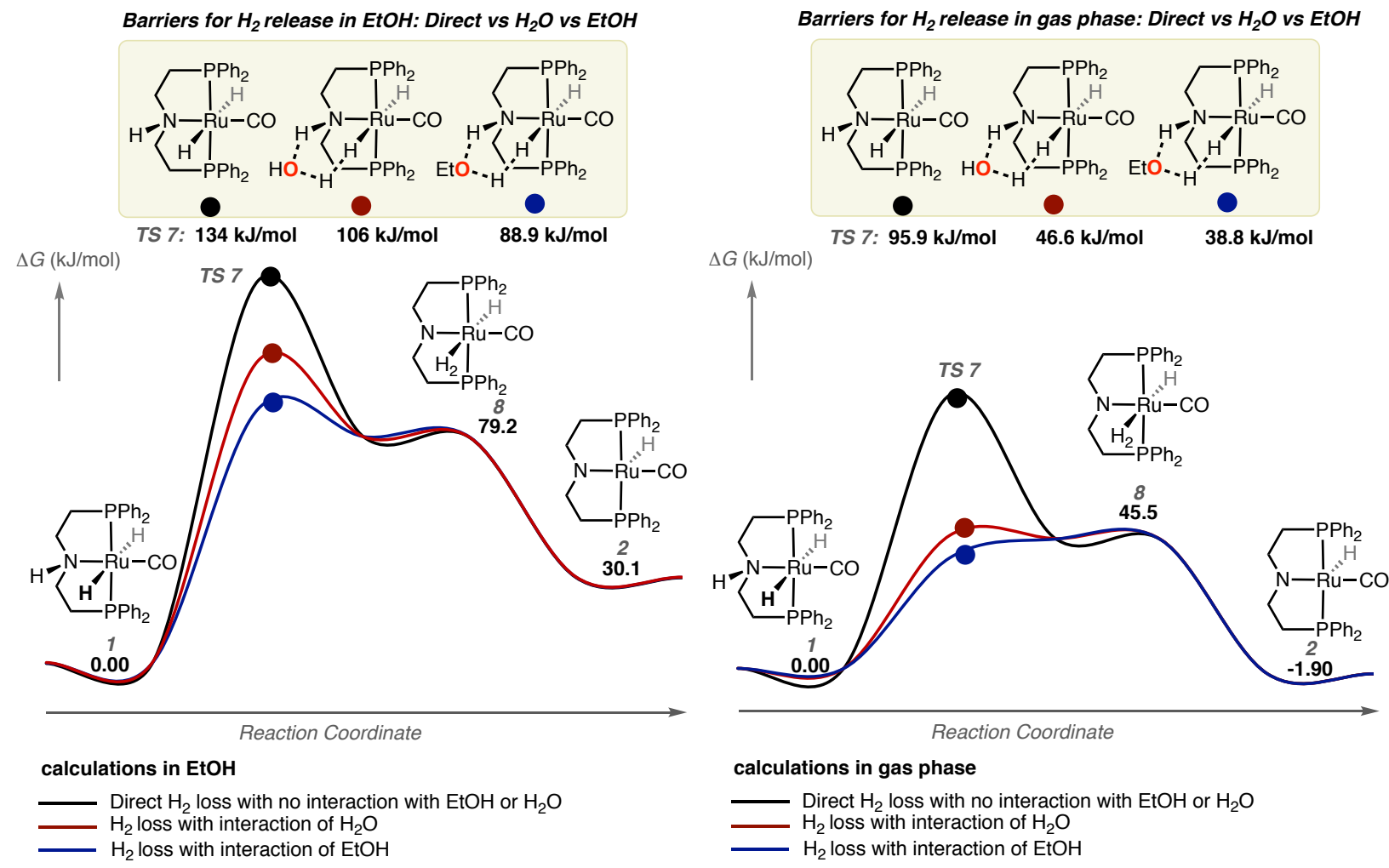

Figure S8. Hydrogen evolution steps from catalyst ground state. All free energies in $\mathrm{kJ} / \mathrm{mol}$. Green energies are in EtOH solvent and blue energies are in the gas phase. The $\mathrm{Ru}-\left(\mathrm{H}_{2}\right)$ adduct at $79.2 \mathrm{~kJ} / \mathrm{mol}(\mathrm{EtOH})$ and $45.5 \mathrm{~kJ} / \mathrm{mol}$ (gas phase) after the formation of the $\mathrm{H}_{2}$ molecular is transient and should not be treated as an intermediate because of its high energy.

Hydrogen evolution from the starting state of the catalyst, 1, is shown in Figure S8. As identified by previous work ${ }^{11,12}$, two options exist: the $\mathrm{H}-\mathrm{H}$ bond can be made directly, across the Ru-N bond, or it can be assisted by a bridging species. In our work, two species can bridge: EtOH and $\mathrm{H}_{2} \mathrm{O}$. All three possibilities calculated above. Similar to work by Ke and co-workers, the bridged transition states are lower in energy, likely due to their ability to overcome the steric strain. The $\mathrm{EtOH}$-bridged species is the lowest in energy and features a longer distance between $\mathrm{O}$ and the transferring proton than the $\mathrm{H}_{2} \mathrm{O}$-bridged TS (1.92 and $1.72 \AA$, respectively). All complexes lead to the formation of putative intermediate $\mathbf{8}$. This intermediate is high in energy and is likely short lived, allowing for the formation of 2 and the ADC cycle to commence. The barriers for TS 7 are higher than any along the dehydrogenation pathways. This implies that the rate determining steps are indeed $\mathrm{H}_{2}$ evolution. This is supported by experimental methods as well, which is detailed in the main text.

There is some discussion in the literature about whether or not the solvent is the source of the proton, rather than the ligand (see work by Dub and coworkers ${ }^{13}$ ). The IRC calculations on TS 7 with bridging $\mathrm{EtOH}$, which according to Dub is diagnostic, shows that the proton transfer from $\mathrm{EtOH}$ is asynchronous from proton transfer to $\mathrm{EtOH}$ from the ligand. This supports Dub's view 
that the solvent is the true source of the proton for $\mathrm{H}_{2}$ evolution, rather than the ligand. The ligand is subsequently deprotonated.

\section{Deactivation}

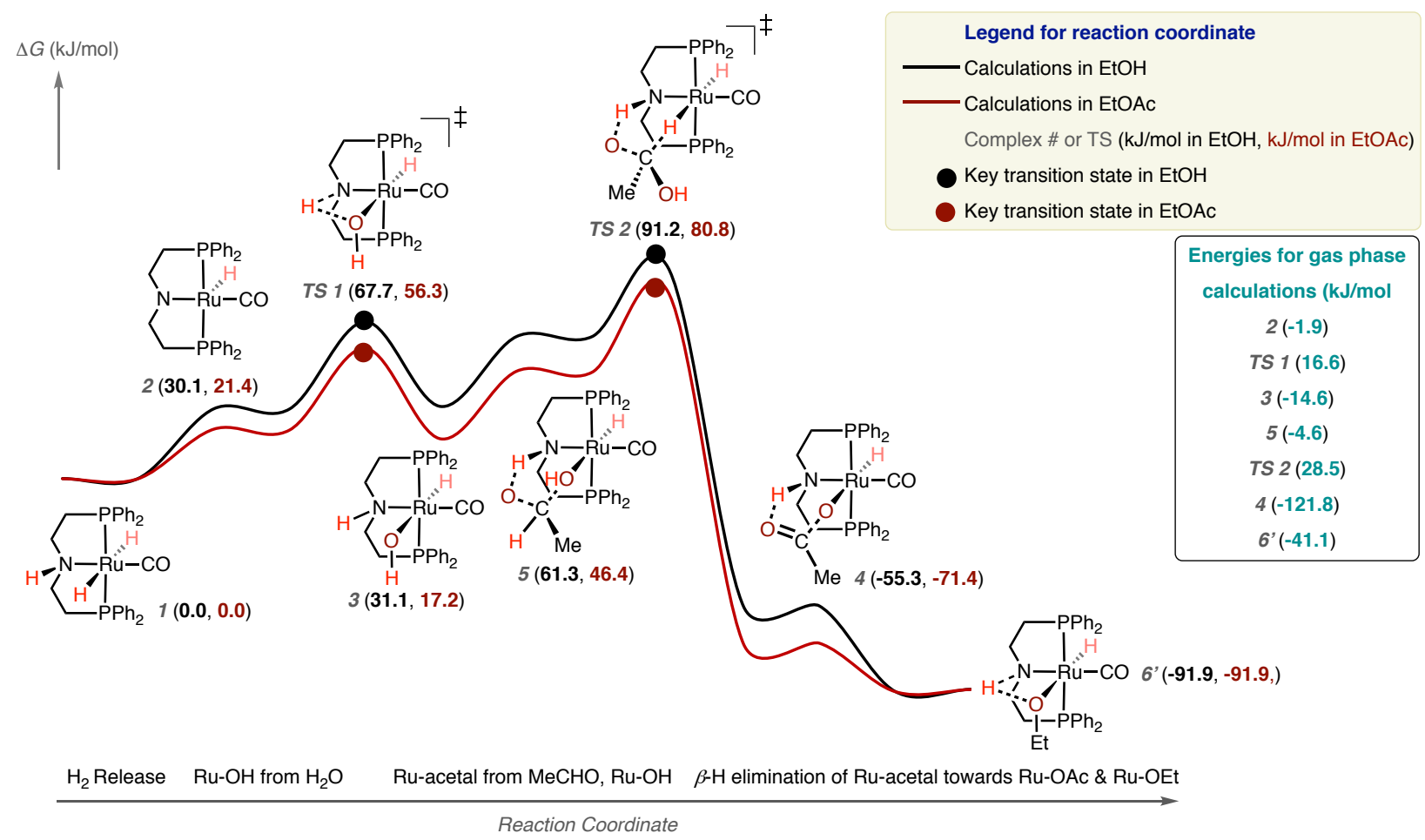

Figure S9. Deactivation pathway through water binding to form an acetate complex. Green energies are in $\mathrm{EtOH}$ solvent, purple energies are in EtOAc solvent, and blue energies are in the gas phase.

Gauvin and coworkers identified $\mathbf{4}$ as being the primary deactivation product and posited that its formation came via addition of water across the Ru-N bond. ${ }^{14}$ Here, we use density functional theory to evaluate the proposed pathway and compare it to those seen in Figs. S6 and S8. Similar to $\mathrm{EtOH}$, water can bind across the Ru-N bond. The barrier for water binding is about $12 \mathrm{~kJ} / \mathrm{mol}$ higher than the analogous process for $\mathrm{EtOH}$, which means it will be slower, but is still feasible. Once water is bound, an acetaldehyde molecule, a product of the on-path cycle, can interact to form 5. Hydride transfer from this state is uphill by $91.2 \mathrm{~kJ} / \mathrm{mol}$, which is quite a bit higher than the analogous $\mathrm{EtOH}$ process. Again, this is feasible, but will further slow the deactivation process relative to our desired ADC pathway. Despite the higher barrier, deactivation is also driven by the formation of 4 , which at $-55.3 \mathrm{~kJ} / \mathrm{mol}$ is a thermodynamic sink. Direct loss of acetate into solution is not possible, as it is uphill by $47.4 \mathrm{~kJ} / \mathrm{mol}$ from 4 . Gauvin noted that 4 could be regenerated with the addition of base. ${ }^{14}$ Indeed, exchange of acetate for EtO- is thermodynamically feasible, as shown by the low energy of $\mathbf{6}^{\prime}$.

All reaction energies along the path are lowered in EtOAc solvent, similar to what is seen in EtOH ADC. One difference, however, is the lowering TS 1 relative to TS 3. In the on-path EtOH binding transition state, TS 3, the barrier is equivalent in the two solvents. However, the barrier for the onset of the deactivation pathway, TS 1, is lowered in EtOAc, making it nearly equivalent to TS 3. This implies that reaction in pure EtOAc solvent, will make deactivation more competitive with the preferred ADC pathway and supports the goal of $75 \%$ conversion discussed in the main text. 


\section{Supplementary Material for Table 1}

Seasonal Microgrid Requirements: The hydrogen throughput and storage requirements for a seasonal microgrid were taken from Pauksztat et. al [1] where a community near Berlin, Germany is assumed to be power self-sufficient. In this case study solar power is stored using batteries and hydrogen. The study estimated a storage requirement of $5100 \mathrm{~kg} \mathrm{H}_{2}$ to provide power during approximately 12 hours per day during three of the winter months.

For the system described in the section "Determining the size of reactor and storage tank for a neighborhood microgrid based on kinetic data," the assumed system consists of a tank/reaction vessel, two heat exchangers and two knock-out pots, a compressor, hydrogen burner with heating loop, and a fuel cell as shown in Figure A.1.

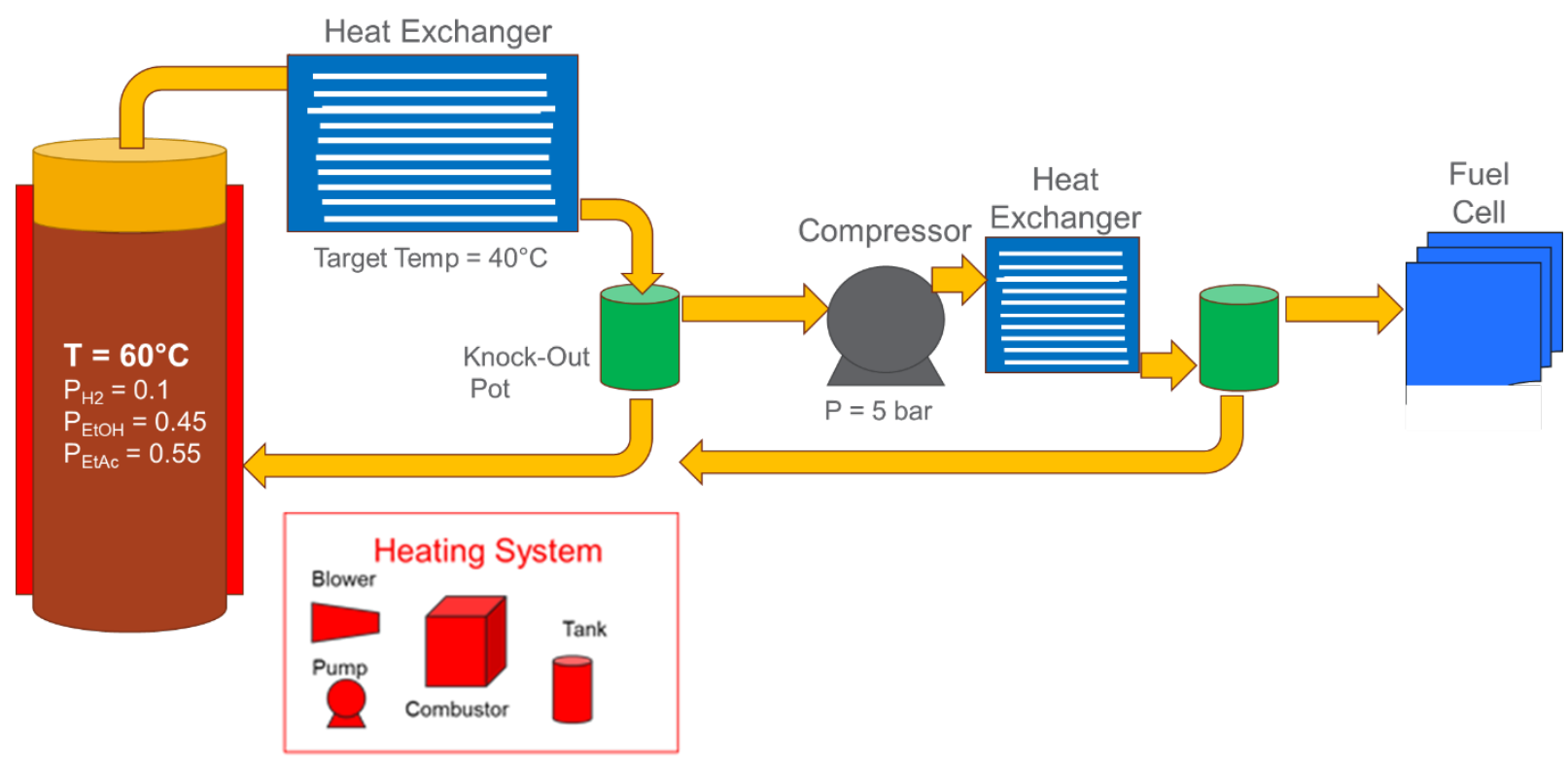

Figure A.1: Process flow diagram for a seasonal microgrid hydrogen storage system based on ethanol/ethyl acetate.

The parameters used in the calculation are shown in Table A.1 and A2. The calculations are as follows.

Impact of Ethanol and Ethyl Acetate Vapor Pressure. At the reaction conditions shown in Table A.1, there is a significant impact of vapor pressure of both ethanol (EtOH) and ethyl acetate (EtOAc). As a result, $90 \%$ of the product is non-hydrogen vapors. Heat must be added to the tank to maintain the temperature as the product and reactant vaporize. Furthermore, the vapors generated must be condensed and returned to the tank at the reaction conditions. In this particular use case, we will assume that external power is provided to the system for these heating and cooling requirements. It is also possible (although not done here) that this heat/cooling has to be provided by burning or producing electricity from the hydrogen being stored as ethanol and as a result, this significantly increases the amount of hydrogen storage required. 
Hydrogen Carrier Quantities. For $5100 \mathrm{~kg}$ used during the course of 3 months, an average of 12 hours per day, the hydrogen use rate is $\mathrm{m}_{\mathrm{H} 2 \mathrm{base}}=4.7 \mathrm{~kg} / \mathrm{hr}$. For the required mass flow of hydrogen, the total amount of ethanol $\left(\mathrm{V}_{\mathrm{EtOH}}\right)$ required can be described as shown in Equation A.2. This calculation includes the total reaction time during the winter $(\mathrm{t})$, hydrogen capacity of ethanol $\left(\mathrm{f}_{\mathrm{H} 2}\right)$, fractional reaction conversion (X) of $75 \%$, and density.

$V_{E t O H}=\frac{t m_{H 2 t o t a l}}{f_{H 2} X \rho_{E t O H}}=163 \mathrm{~m}^{3} \mathrm{EtOH}$ (A.1)

If 12 cylindrical tanks are assumed to store this ethanol, each would have a volume of $14 \mathrm{~m}^{3}$. Assuming a height to diameter ratio of 1.5 , the tanks would be $2.3 \mathrm{~m}$ diameter and $3.4 \mathrm{~m}$ tall. In this case an aluminum tank with a thickness of $1.5 \mathrm{~cm}$ is assumed. The mass of these dished head tanks can be calculated (Equation A.2).

Tank Mass $=\frac{\pi}{4} \rho_{\text {Al }}\left\{\left[\left(D_{\text {tank }}+2 t_{\text {wall }}\right)^{2}-D_{\text {tank }}^{2}\right] H_{\text {tank }}+\frac{1}{3}\left[\left(D_{\text {tank }}+2 t_{\text {wall }}\right)^{3}-D_{\text {tank }}^{3}\right]\right\}$

Tank Mass $=1310 \mathrm{~kg}$ (A.2)

Ethanol Reaction. Under the assumed conditions of a zero-order reaction, the rate of production of hydrogen is constant. Based on the extrapolated experimental reaction time of 64.5 hours $\left(\mathrm{t}_{\mathrm{rxn}}\right)$ to achieve $\mathrm{X}=75 \%$ conversion, this would require a volume of ethanol heated to $60^{\circ} \mathrm{C}$ as described in Equation A.3.

$V_{\text {Tank }}=\frac{\dot{m}_{H 2 t o t a l} t_{r \times n}}{f_{H 2} X \rho_{E t O H}}=13 \mathrm{~m}^{3} \mathrm{EtOH}(\mathrm{A} .3)$

Since each tank is $14 \mathrm{~m}^{3}$, the reaction in one tank is more than enough to achieve the required hydrogen production.

Combustor Sizing. The combustor consists of a combustor/heat exchanger, a blower to provide air, and a heat transfer fluid loop with a pump and a storage tank. The heat $\left(\mathrm{Q}_{\text {comb }}\right)$ required for this combustor is the heat of reaction and heat of vaporization as shown in Equation A.4.

$Q_{c o m b}=\frac{\dot{m}_{H 2 t o t a l}}{M W_{H 2}}\left(\Delta H_{r x n}+\frac{\Delta H_{\text {vapEtoH }} P_{E t O H}+\Delta H_{\text {vapEtOAC }} P_{E t O A c}}{P_{H 2}}\right)=211 \mathrm{~kW}$ (A.4)

The sensible heat in this case is assumed to be negligible as it can be recuperated. Assuming a combustor with a $20^{\circ} \mathrm{C}$ heat transfer fluid and a $200^{\circ} \mathrm{C}$ gas phase temperature rise, the mass flow rate of each and the required heat exchanger can be appropriately sized. The heat transfer fluid flow rate $\left(\mathrm{m}_{\text {thf }}\right)$ and the air flow rate $\left(\mathrm{m}_{\text {air }}\right)$ can be calculated as provided below in Equations A.5 and A.6.

$$
\begin{aligned}
& \dot{m}_{h t f}=\frac{Q_{c o m b}}{C_{p h t f} \Delta T_{h t f}}=5.85 \mathrm{~kg} / \mathrm{s} \quad \text { (A.5) } \\
& \dot{m}_{\text {air }}=\frac{Q_{c o m b}}{C_{\text {pair } \Delta T_{\text {gas }}}}=1.05 \mathrm{~kg} / \mathrm{s} \text { (A.6) }
\end{aligned}
$$


The sizing of the heat exchanger can be calculated using the NTU-effectiveness method where NTU can be calculated from the heat exchanger effectiveness $\left(\varepsilon_{\text {comb }}\right)$ and $\mathrm{C}_{\mathrm{r}}=\mathrm{C}_{\min } / \mathrm{C}_{\max }$. The values of $\mathrm{C}_{\min }$ and $\mathrm{C}_{\max }$ are described below in Equation A.7.

$$
C_{\text {min }}=\min \left(\dot{m}_{h t f} C_{p h t f}, \dot{m}_{\text {air }} C_{\text {pair }}\right) \text { and } C_{\text {max }}=\max \left(\dot{m}_{h t f} C_{p h t f}, \dot{m}_{\text {air }} C_{\text {pair }}\right)(\text { A.7) }
$$

For a single pass counter-flow heat exchanger, the number of transfer units (NTU) can be calculated from the following formula provided in Equation A.8.

$N T U=\frac{1}{1-C_{r}} \ln \left(\frac{1-C_{r} \epsilon_{\text {comb }}}{1-\epsilon_{\text {comb }}}\right)=1.7$ (A.8)

The surface area of the heat exchanger $\left(\mathrm{A}_{\mathrm{comb}}\right)$ is calculated based on the definition of NTU (Equation A.10).

$A_{\text {comb }}=\frac{N T U C_{\min }}{h_{\text {comb }}}=44.6 \mathrm{~m}^{2}$

Rather than fully design the heat exchanger, the volume is assumed based on a heat exchanger specific surface area ration $\mathrm{SA}_{\mathrm{HX}}$, which is the area of the heat exchanger per unit volume. Using this parameter, the volume of the combustion heat exchanger is calculated as shown in Equation A.10.

$V_{\text {comb }}=\frac{A_{\text {comb }}}{S A_{H X}}=0.89 \mathrm{~m}^{3}$

The mass of the combustor/heat exchanger is based on the volume and is assumed to be $35 \%$ stainless steel $\left(\rho=8000 \mathrm{~kg} / \mathrm{m}^{3}\right)$ and $65 \%$ open space. As a result, its mass is $2500 \mathrm{~kg}$.

In addition to the heat exchanger, the heating system contains a tank. The size of this heating tank is based on the residence time and the flow rate. Its volume ( $\left.\mathrm{V}_{\mathrm{htf}, \operatorname{tank}}\right)$ can be calculated from the formula below (Equation A.11).

$V_{h t f, t a n k}=\frac{\dot{m}_{h t f} t_{r e s, c o m b}}{\rho_{h t f}}=0.38 \mathrm{~m}^{3}(\mathrm{~A} .11)$

Using a tank length to diameter ratio (LD) of 4 the diameter is estimated as $0.49 \mathrm{~m}$ and the height $1.98 \mathrm{~m}$. These values can be used in the tank mass calculation above with the parameters in Table A.2 to calculate the mass of the aluminum tank. The total mass of the tank includes the mass of heat transfer fluid stored $(351 \mathrm{~kg}$ ) and the mass of the tank $(96 \mathrm{~kg}$ ) (as calculated from Equation A.3). Rather than calculate the mass and volume of the pump, blower, and piping, it is assumed to be $30 \%$ of the mass and volume of the tank and heat exchanger. As a result, the total mass and volume of the combustor system is estimated at $3830 \mathrm{~kg}$ and $1.66 \mathrm{~m}^{3}$.

Heat Exchanger Sizing. The first heat exchanger is assumed to be air cooled to reduce the temperature of the products from a reaction temperature of $60^{\circ} \mathrm{C}$ to a target of $40^{\circ} \mathrm{C}$. For this calculation, the primary cooling needed is to condense out the vapor phase ethanol and ethyl acetate. The sensible heat of cooling the $\mathrm{H}_{2}$ is negligible relative to the heat of vaporization of 
these two species. In the first heat exchanger, $90 \%$ of the vapors are assumed to be removed. The heat removal requirement is provided in Equation A.12.

$Q_{H X}=\frac{\dot{m}_{H 2 t o t a l} f_{\text {condens }}}{M W_{H 2}}\left(\frac{\Delta H_{\text {vapEtoH }} P_{E t O H}+\Delta H_{v a p E t o A c} P_{E t O A c}}{P_{H 2}}\right)=191 \mathrm{~kW}$ (A.12)

To calculate the size of the heat exchanger, a similar $\varepsilon$-NTU method is used as was done for the combustor. The heat capacity ratio $\left(\mathrm{C}_{\mathrm{r}}\right)$ in this case is calculated from the temperature streams associated with the heat exchanger as described in Table A.2 and Equation A.13.

$C_{r}=\frac{\left(T_{\text {air }, o}-T_{\infty}\right)}{\left(T_{r \times n}-T_{\text {target }}\right)}=0.25(\mathrm{~A} .13)$

The NTU can be calculated for a cross-flow heat exchanger heat exchanger according to Equation A.14.

$N T U=\ln \left(\frac{1}{1+1 / C_{r} \ln \left(1-C_{r} \epsilon_{H X}\right)}\right)=1.46(\mathrm{~A} .14)$

The mass flow of air through the heat exchanger can be calculated from the heat capacity and temperature differential as follows in Equation A.15.

$\dot{m}_{\text {air }}=\frac{Q_{H X}}{C_{\text {pair }}\left(T_{\text {air }, o}-T_{\infty}\right)}=38.2 \mathrm{~kg} / \mathrm{s}$

With the mass flow of air, the surface area of the heat exchanger can be calculated as shown in Equation A.16.

$A_{H X}=\frac{N T U \dot{m}_{a i r} C_{p, a i r}}{h_{H X}}=1233 \mathrm{~m}^{2}(\mathrm{~A} .16)$

Based on a surface area to volume ratio of 50, similar to the combustor, the volume of the heat exchanger calculated in Equation A.17.

$V_{H X}=\frac{A_{H X}}{S A_{H X}}=24.7 \mathrm{~m}^{3}(\mathrm{~A} .17)$

The mass of the combustor/heat exchanger is based on the volume and is assumed to be $20 \%$ aluminum $\left(\rho=2700 \mathrm{~kg} / \mathrm{m}^{3}\right)$ and $80 \%$ open space. As a result, its mass is $16,000 \mathrm{~kg}$. As with the combustor, rather than calculate the mass and volume of the blower and piping, this balance of plant is assumed to be $20 \%$ of the mass and volume of the tank and heat exchanger. As a result, the total mass and volume of the combustor system is estimated at $19,200 \mathrm{~kg}$ and $29.6 \mathrm{~m}^{3}$.

Knock-Out Pot Sizing. The knock-out pot is sized based on the residence time of the gases flowing through it. Because it is at low temperature and pressure, it is assumed to be a plastic tank. The flow rate of gases is based on mass flow of hydrogen under conditions of the target temperature and system pressure assuming the ideal gas law. The volume of the tank $\left(\mathrm{V}_{\mathrm{kop}}\right)$ can be calculated as described in Equation A.18. 
$V_{\text {kop }}=\frac{\dot{m}_{\text {H2total }} R T_{\text {target }}}{M W_{H 2} P} \tau_{k o p}=0.05 \mathrm{~m}^{3}(\mathrm{~A} .18)$

Using a tank length to diameter ratio $\left(\mathrm{HD}_{\mathrm{kop}}\right)$ of 1 the diameter and diameter are estimated as $0.40 \mathrm{~m}$. These values can be used in the tank mass calculation above with the parameters in Table A.2 to calculate the mass of the plastic tank of $7.7 \mathrm{~kg}$.

Compressor Sizing. After the heat exchanger, the hydrogen and remaining vapors are compressed to 5 bar. The required compressor power $\left(\mathrm{P}_{\text {comp }}\right)$ in horsepower can be estimated assuming adiabatic conditions using Equation A.19.

$P_{\text {comp }}=\frac{\dot{v}_{\text {H2total }} 1.8\left(T_{\text {target }}+273\right)}{8130 \varepsilon_{\text {comp }}(\gamma-1) / \gamma}\left(\frac{P_{f}}{P_{i}}\right)^{(\gamma-1) / \gamma}=4.3 \mathrm{hp} \mathrm{(A.19)}$

where $\dot{v}_{H 2 \text { total }}$ can be calculated from $\dot{m}_{H 2 \text { total }}$ under STP conditions as $26 \mathrm{scfm}$. The mass and volume of such a compressor is assumed from a FlowServe SIHI Model to be approximately 75 $\mathrm{kg}$ and 56 liters, respectively. A GE D427 $10 \mathrm{hp} \mathrm{DC} \mathrm{motor} \mathrm{was} \mathrm{assumed} \mathrm{for} \mathrm{a} \mathrm{mass} \mathrm{and} \mathrm{volume}$ of $114 \mathrm{~kg}$ and 130 liters, respectively. The BOP volume of such a system is assumed be $50 \%$ of the volume of the compressor and motor while the BOP mass is assumed to be $20 \%$ of the mass. The total compressor system mass and volume are $227 \mathrm{~kg}$ and $0.28 \mathrm{~m}^{3}$, respectively.

The adiabatic temperature rise in the compressor can be calculated using Equation A.20.

$T_{\text {comp }}=\left(T_{\text {target }}+273\right)\left(\frac{P_{f}}{P_{i}}\right)^{(\gamma-1) / P_{f}}-273=80^{\circ} \mathrm{C} \quad($ A. 20$)$

Second Heat Exchanger. The second heat exchanger sizing can be calculated similar to the first except that we will include the sensible heat of hydrogen associated with cooling from $80^{\circ} \mathrm{C}$ to the target temperature of $40^{\circ} \mathrm{C}$ as shown in Equation A.21.

$$
\begin{aligned}
& Q_{H X 2}=\dot{m}_{H 2 \text { total }}\left\{\frac{\left(1-f_{\text {condens }}\right)}{M W_{H 2}}\left(\frac{\Delta H_{\text {vapEtOH }} P_{E t O H}+\Delta H_{\text {vapEtOAC }} P_{E t O A c}}{P}\right)+C_{p H 2}\left(T_{\text {comp }}-T_{\text {target }}\right)\right\} \\
& Q_{H X 2}=2.4 \mathrm{~kW}(\text { A. } 21)
\end{aligned}
$$

Using similar assumptions as before, the total mass and volume of the second heat exchanger are $238 \mathrm{~kg}$ and $0.37 \mathrm{~m}^{3}$, respectively.

Second Knock-Out Pot Sizing. As before the knock-out pot is sized based on the residence time of the gases flowing through it. The only value that has changed is the pressure. As a result, the volume of the second knock-out pot would be approximately $1 / 5^{\text {th }}$ the size due to the $5 \mathrm{x}$ increase in pressure (See Equation A.22)

$V_{k o p 2}=\frac{\dot{m}_{H 2 t o t a l} R T_{\text {target }}}{M W_{H 2} P_{\text {comp }}} \tau_{k o p}=0.01 \mathrm{~m}^{3}(\mathrm{~A} .22)$ 
Using the same tank length to diameter ratio $\left(\mathrm{HD}_{\mathrm{kop}}\right)$ of 1 the diameter and height are estimated as $0.23 \mathrm{~m}$. These values can be used in the tank mass calculation above with the parameters in Table A.2 and Equation A.2 to calculate the mass of the plastic tank of $3.5 \mathrm{~kg}$.

Fuel Cell Sizing. Using the specific mass and specific volume of a fuel cell system provided by DOE as 2020 targets for an $80 \mathrm{kWe}$ fuel cell system of $650 \mathrm{~W} / \mathrm{L}$ and $650 \mathrm{~W} / \mathrm{kg}$, the mass and volume of the fuel cell can also be estimated. In this case the fuel cell would be for a $65.6 \mathrm{kWe}$ system, as a result, the mass and volume would be $100 \mathrm{~kg}$ and $0.1 \mathrm{~m}^{3}$, respectively.

Summary. The total system mass can be estimated by summing all of thee above components. Each tank is $12,000 \mathrm{~kg}$ (full) and the twelve tanks combined with all the balance of plant results in a system mass of $168,000 \mathrm{~kg}$. Each tank is $14 \mathrm{~m} 3$ in volume and the twelve tanks combined with all the balance of plant results in a system volume of $196 \mathrm{~m}^{3}$. Approximately $211 \mathrm{~kW}$ of heating is required and $193 \mathrm{~kW}$ of cooling.

Table SA.1: Material, Tank and Reaction Properties for a seasonal microgrid hydrogen storage system based on ethanol/ethyl acetate

\begin{tabular}{|c|c|c|c|c|c|c|c|c|}
\hline \multicolumn{3}{|c|}{ Material Properties } & \multicolumn{3}{|c|}{ Tank Properties } & \multicolumn{3}{|c|}{ Reaction Conditions } \\
\hline Property & Value & Units & Property & Value & Units & Property & Value & Units \\
\hline $\begin{array}{l}\text { EtOH Mole. } \\
\text { Weight }\left(\mathrm{MW}_{\mathrm{EtOH}}\right)\end{array}$ & 46.07 & $\mathrm{~g} / \mathrm{mol}$ & Tank Pressure (P) & 1.1 & Bar & Temperature $\left(\mathrm{T}_{\mathrm{rxn}}\right)$ & 60 & ${ }^{\circ} \mathrm{C}$ \\
\hline $\begin{array}{l}\text { Reaction Enthalpy } \\
\left(\Delta \mathrm{H}_{\mathrm{rxn}}\right)\end{array}$ & 35.9 & $\mathrm{~kJ} / \mathrm{mol}$ & Tank Material & $\mathrm{Al}$ & -- & Catalyst & Ru-Ma & \\
\hline $\begin{array}{l}\text { Gravimetric Cap. } \\
\left(\mathrm{f}_{\mathrm{H} 2}\right)\end{array}$ & 0.044 & $\mathrm{~g} \mathrm{H}_{2} / \mathrm{g}$ & $\begin{array}{l}\text { Height to Diam } \\
\left(\mathrm{HD}_{\mathrm{t}}\right)\end{array}$ & 4 & -- & Catalyst Conc. & 250 & ppm \\
\hline $\begin{array}{l}\mathrm{H}_{2} \text { Specific Heat } \\
\left(\mathrm{C}_{\mathrm{pH} 2}\right)\end{array}$ & 14300 & $\mathrm{~J} / \mathrm{kg} / \mathrm{K}$ & $\begin{array}{l}\text { Wall Thickness } \\
\left(t_{\text {wall }}\right)\end{array}$ & 1.5 & $\mathrm{Cm}$ & $\begin{array}{l}\text { Conversion } \\
(\mathrm{X}=75 \%) \text { time }\end{array}$ & 64.5 & Hours \\
\hline $\begin{array}{l}\text { EtOH Specific Heat } \\
\left(\mathrm{C}_{\mathrm{pEtOH}}\right)\end{array}$ & 2570 & $\mathrm{~J} / \mathrm{kg} / \mathrm{K}$ & Number Tanks & 12 & -- & $\begin{array}{l}\mathrm{H}_{2} \text { Partial Pressure } \\
\left(\mathrm{P}_{\mathrm{H} 2}\right)\end{array}$ & 0.1 & bar \\
\hline $\begin{array}{l}\text { EtOH } \Delta \mathrm{H} \text { Vapor. } \\
\left(\Delta \mathrm{H}_{\mathrm{vap}, \mathrm{EtOH}}\right)\end{array}$ & 38.45 & $\mathrm{~kJ} / \mathrm{mol}$ & $\begin{array}{l}\text { Aluminum Density } \\
\left(\rho_{\mathrm{Al}}\right)\end{array}$ & 2700 & $\mathrm{~kg} / \mathrm{m}^{3}$ & $\begin{array}{l}\text { EtOH Partial } \\
\text { Pressure }\left(\mathrm{P}_{\mathrm{EtOH}}\right)\end{array}$ & 0.45 & bar \\
\hline $\mathrm{H}_{2} \operatorname{LHV}\left(\Delta \mathrm{H}_{\mathrm{comb}}\right)$ & 240 & $\mathrm{~kJ} / \mathrm{mol}$ & $\begin{array}{l}\text { Total Reaction } \\
\text { time }(\mathrm{t})\end{array}$ & 1080 & hrs & $\begin{array}{l}\text { EtOAc Partial } \\
\text { Pressure }\left(\mathrm{P}_{\mathrm{EtOAc}}\right)\end{array}$ & 0.55 & bar \\
\hline $\begin{array}{l}\text { EtOH Density } \\
\left(\rho_{\mathrm{EtOH}}\right)\end{array}$ & 789 & $\mathrm{~kg} / \mathrm{m}^{3}$ & & & & & & \\
\hline $\begin{array}{l}\text { EtOAc } \Delta \mathrm{H} \text { Vapor. } \\
\left(\Delta \mathrm{H}_{\mathrm{vap}, \mathrm{EtOAc})}\right.\end{array}$ & 31.94 & $\mathrm{~kJ} / \mathrm{mol}$ & & & & & & \\
\hline
\end{tabular}

Table SA.2: Combustor, Fuel Cell, Compressor, Knock-Out Pot, and Heat Exchanger Properties for a seasonal microgrid hydrogen storage system based on ethanol/ethyl acetate

\begin{tabular}{|c|c|c|c|c|c|c|c|c|}
\hline \multicolumn{3}{|c|}{ Combustor Properties } & \multicolumn{3}{|c|}{$\begin{array}{c}\text { Fuel Cell } \\
\end{array}$} & \multicolumn{3}{|c|}{ Knock-Out Pots } \\
\hline Property & Value & Units & Property & Value & Units & Property & Value & Units \\
\hline $\begin{array}{l}\text { Air heat capacity } \\
\left(\mathrm{C}_{\mathrm{pair}}\right)\end{array}$ & 1000 & $\mathrm{~J} / \mathrm{kg} / \mathrm{K}$ & $\begin{array}{l}\text { Power Density } \\
\text { (PD) }\end{array}$ & 650 & $\mathrm{~W} / \mathrm{L}$ & Residence Time $\left(\tau_{\mathrm{kop}}\right)$ & 4 & sec \\
\hline $\begin{array}{l}\text { Heat Transfer } \\
\text { Coefficient } \\
\left(\mathrm{h}_{\text {comb }}\right) \\
\end{array}$ & 40.0 & $\mathrm{~W} / \mathrm{m} 2 / \mathrm{K}$ & $\begin{array}{l}\text { Fuel Cell } \\
\text { Efficiency }\left(\varepsilon_{\mathrm{FC}}\right)\end{array}$ & 16.6 & $\mathrm{kWh} / \mathrm{kg}$ & $\begin{array}{l}\text { Height/Diameter } \\
\left(\mathrm{HD}_{\text {kop }}\right)\end{array}$ & 1 & -- \\
\hline
\end{tabular}




\begin{tabular}{|c|c|c|c|c|c|c|c|c|}
\hline $\begin{array}{l}\text { Combustor } \\
\text { Effectiveness } \\
\left(\varepsilon_{\text {comb }}\right) \\
\end{array}$ & $80 \%$ & & $\begin{array}{l}\text { Specific Power } \\
\text { (SP) }\end{array}$ & 650 & $\mathrm{~W} / \mathrm{kg}$ & Wall Thickness ( $\left.t_{\text {kop }}\right)$ & 1 & $\mathrm{~cm}$ \\
\hline $\begin{array}{l}\text { Heating Fluid } \\
\text { Heat Capacity } \\
\left(\mathrm{C}_{\text {phxf }}\right)\end{array}$ & 1800 & $\mathrm{~J} / \mathrm{kg} / \mathrm{K}$ & \multicolumn{3}{|c|}{ Compressor } & \multicolumn{3}{|c|}{ Heat Exchangers } \\
\hline $\begin{array}{l}\text { Heating Fluid } \\
\text { Density }\left(\rho_{\mathrm{hxf}}\right)\end{array}$ & 0.92 & $\mathrm{~kg} / \mathrm{L}$ & Property & Value & Units & Property & Value & Units \\
\hline $\begin{array}{l}\text { Heating Fluid } \\
\text { Temperature Rise } \\
\left(\Delta \mathrm{T}_{\mathrm{htf}}\right)\end{array}$ & 20 & ${ }^{\circ} \mathrm{C}$ & $\begin{array}{c}\text { Initial Pressure } \\
\left(\mathrm{P}_{\mathrm{i}}\right)\end{array}$ & 0.1 & bar & $\begin{array}{l}\text { Ambient Temperature } \\
\left(\mathrm{T}_{\infty}\right)\end{array}$ & 30 & ${ }^{\circ} \mathrm{C}$ \\
\hline $\begin{array}{l}\text { HX Specific Area } \\
\text { Density }\left(\mathrm{SA}_{\mathrm{HX}}\right)\end{array}$ & 50 & $\mathrm{~m} 2 / \mathrm{m} 3$ & $\begin{array}{l}\text { Final Pressure } \\
\left(\mathrm{P}_{\mathrm{f}}\right)\end{array}$ & 5 & bar & $\begin{array}{l}\text { Target Temperature } \\
\left(\mathrm{T}_{\text {target }}\right)\end{array}$ & 40 & ${ }^{\circ} \mathrm{C}$ \\
\hline $\begin{array}{l}\text { Gas Temperature } \\
\text { Rise }\left(\Delta \mathrm{T}_{\mathrm{gas}}\right)\end{array}$ & 200 & ${ }^{\circ} \mathrm{C}$ & $\begin{array}{l}\text { Specific Heat } \\
\text { Ratio }(\gamma)\end{array}$ & 1.4 & -- & $\begin{array}{l}\text { Exit Air Temperature } \\
\left(T_{\text {air }, o}\right)\end{array}$ & 35 & ${ }^{\circ} \mathrm{C}$ \\
\hline $\begin{array}{l}\text { HX Volume } \\
\text { Fraction Metal } \\
\left(f_{\text {HXmetal }}\right)\end{array}$ & $35 \%$ & & $\begin{array}{l}\text { Efficiency } \\
\left(\varepsilon_{\text {comp }}\right)\end{array}$ & $80 \%$ & -- & $\begin{array}{l}\text { HX Effectiveness } \\
\left(\varepsilon_{\mathrm{HX}}\right)\end{array}$ & $70 \%$ & -- \\
\hline $\begin{array}{l}\text { Heating Tank } \\
\text { Residence Time } \\
\left(\mathrm{t}_{\text {res,comb }}\right)\end{array}$ & 60 & $\sec$ & BOP Volume & $50 \%$ & -- & $\begin{array}{l}\text { Heat Transfer } \\
\text { Coefficient }\left(\mathrm{h}_{\mathrm{HX}}\right)\end{array}$ & 45 & $\mathrm{~W} / \mathrm{m}^{2} / \mathrm{K}$ \\
\hline $\begin{array}{l}\text { Heating Tank } \\
\text { L/D (LD) }\end{array}$ & 4 & & BOP Mass & $20 \%$ & -- & $\begin{array}{l}\text { Fraction Vapors } \\
\text { Condensed in } 1^{\text {st }} \mathrm{HX}\end{array}$ & $90 \%$ & \\
\hline $\begin{array}{l}\text { BOP Heating } \\
\left.\text { System (f } \text { f }_{\text {BOPcomb }}\right)\end{array}$ & $30 \%$ & & & & & $\begin{array}{l}\text { BOP HX System } \\
\left(f_{\text {BOPHX }}\right)\end{array}$ & $20 \%$ & \\
\hline
\end{tabular}

1. Pauksztat, A., Saliger, R. \& Boyanov, N. Residential Energy Supply Concept with Integration of Renewable Energies and Energy Storage. Chemical Engineering \& Technology 42, 1907-1913, doi:10.1002/ceat.201800634 (2019). 


\section{References}

1. Becke, A. D., A New Mixing of Hartree - Fock and Local Density - Functional Theories. J. Chem. Phys. 1993, 98, 1372-1377, DOI:10.1063/1.464304.

2. Lee, C. T.; Yang, W. T.; Parr, R. G., Development of the Colle-Salvetti Correlation-Energy Formula into a Functional of the Electron Density. Phys. Rev. B 1988, 37, 785-789, DOI:10.1103/PhysRevB.37.785.

3. Francl, M. M.; Pietro, W. J.; Hehre, W. J.; Binkley, J. S.; Gordon, M. S.; Defrees, D. J.; Pople, J. A., Self-Consistent Molecular Orbital Methods. 23. a Polarization-Type Basis Set for 2nd Row Elements. J. Chem. Phys. 1982, 77, 3654-3665, DOI:10.1063/1.444267.

4. Hehre, W. J.; Ditchfie.R; Pople, J. A., Self-Consistent Molecular Orbital Methods. 12. Further Extensions of Gaussian-Type Basis Sets for Use in Molecular Orbital Studies of Organic Molecules. J. Chem. Phys. 1972, 56, 2257-2261, DOI:10.1063/1.1677527.

5. Weigend, F.; Ahlrichs, R., Balanced Basis Sets of Split Valence, Triple Zeta Valence and Quadruple Zeta Valence Quality for $\mathrm{H}$ to Rn: Design and Assessment of Accuracy. Phys. Chem. Chem. Phys. 2005, 7, 3297-3305, DOI:10.1039/B508541A.

6. Andrae, D.; Häußermann, U.; Dolg, M.; Stoll, H.; Preuß, H., Energy-Adjustedab Initio Pseudopotentials for the Second and Third Row Transition Elements. Theor. Chim. Acta 1990, 77, 123-141, DOI:10.1007/BF01114537.

7. Grimme, S.; Ehrlich, S.; Goerigk, L., Effect of the Damping Function in Dispersion Corrected Density Functional Theory. J. Comp. Chem. 2011, 32, 1456-1465, DOI:10.1002/jcc.21759.

8. Grimme, S.; Antony, J.; Ehrlich, S.; Krieg, H., A Consistent and Accurate Ab Initio

Parametrization of Density Functional Dispersion Correction (DFT-D) for the 94 Elements H-Pu. J. Chem. Phys. 2010, 132, 154104, DOI:10.1063/1.3382344.

9. Marenich, A. V.; Cramer, C. J.; Truhlar, D. G., Universal Solvation Model Based on Solute Electron Density and on a Continuum Model of the Solvent Defined by the Bulk Dielectric Constant and Atomic Surface Tensions. J. Phys. Chem. B 2009, 113, 6378-6396, DOI:10.1021/jp810292n.

10. Neese, F., Software Update: The ORCA Program System, Version 4.0. Wiley Interdiscip. Rev. Comput. Mol. Sci. 2017, 8, e1327, DOI:10.1002/wcms.1327.

11. Tindall, D. J.; Menche, M.; Schelwies, M.; Paciello, R. A.; Schäfer, A.; Comba, P.; Rominger, F.; Hashmi, A. S. K.; Schaub, T., Ru0 or Rull: A Study on Stabilizing the "Activated" Form of RuPNP Complexes with Additional Phosphine Ligands in Alcohol Dehydrogenation and Ester Hydrogenation. Inorg. Chem. 2020, 59, 5099-5115, DOI:10.1021/acs.inorgchem.0c00337. 12. Shu, S.; Huang, M.; Jiang, J.; Qu, L.-B.; Liu, Y.; Ke, Z., Catalyzed or Non-Catalyzed: Chemoselectivity of Ru-Catalyzed Acceptorless Dehydrogenative Coupling of Alcohols and Amines via Metal-ligand Bond Cooperation and (De)aromatization. Catalysis Science \& Technology 2019, 9, 2305-2314, DOI:10.1039/C9CY00243J.

13. Dub, P. A.; Gordon, J. C., Metal-Ligand Bifunctional Catalysis: The "Accepted" Mechanism, the Issue of Concertedness, and the Function of the Ligand in Catalytic Cycles Involving Hydrogen Atoms. ACS Catalysis 2017, 7, 6635-6655, DOI:10.1021/acscatal.7b01791. 14. Nguyen, D. H.; Trivelli, X.; Capet, F.; Swesi, Y.; Favre-Réguillon, A.; Vanoye, L.; Dumeignil, F.; Gauvin, R. M., Deeper Mechanistic Insight into Ru Pincer-Mediated Acceptorless Dehydrogenative Coupling of Alcohols: Exchanges, Intermediates, and Deactivation Species. ACS Catal. 2018, 8, 4719-4734, DOI:10.1021/acscatal.8b00995. 